\title{
THE BASE OF REDEFINING SOCIAL CAPITAL IN THE CONDITIONS OF AGRARIAN SECTOR IN THE CZECH REPUBLIC
}

\author{
Received: December 15, 2005
}

\begin{abstract}
N. Pomazalová
Abstract

POMAZALOVÁ, N.: The base of redefining social capital in the conditions of agrarian sector in the Czech Republic. Acta univ. agric. et silvic. Mendel. Brun., 2006, LIV, No. 3, pp. 175-182

The aim of the article is to provide a survey of approaches to the investigation of social capital. And the another purpose is to present a proposal for a concept of social capital that would make it possible to quantify the market-unrealised capital potential with respect to sustainable development of multifunctional agriculture. For identification of social capital due to the specificities of our conditions mobilizational individual capital and its manifestations in identification with the environment is in order to capture the individual dimensions of the approache mentioned.
\end{abstract}

concepts of capital, forms of social capital, locality/region, sustainable development, multifunctional agriculture

A background study is being prepared within the framework of the research intention of the thematic aim 05 in the year 2005, to serve as an introduction to the investigation of social capital in the conditions of the Czech Republic locality/region, with respect to sustainable development of multifunctional agriculture. In view of the specificity of the post-totalitarian environment it is not possible to use measurements of social capital with such a range and quality as is presented in foreign literature. The aim of the background study is to provide a survey of approaches to the investigation of social capital and to present a proposal for a concept of social capital that would make it possible, in accordance with the goal of the subtask of the thematic aim 05 , to quantify the market-unrealised capital potential with respect to sustainable development of multifunctional agriculture. These steps will be also tied to the creation of a research tool that would make it possible to measure such a quantification.

These requirements are linked to efforts to objectify and revitalize transfers, especially of economic capi- tal, which in the global economy are accompanied by certain failings, in the sense that economic goals often bring about negative effects socially or environmentally. To investors, such effects in the social reality are often surprising, since the studies carried out of the localities/regions pointed to the necessity of economic capital. Economic capital flows a priori represent a point of departure for the development of a particular place; however, the agency of the role of the social capital of the inhabitants of the locality/region remains unappreciated. It is possible to anticipate these negative effects by investigating social capital using a metric by means of which it is possible to describe a model defined by inputs (e.g. bonds of informal acquaintance, nepotism, corruption, patronage, protectionism among service providers and consultancy organizations) and outputs (e.g. trust on the part of the consumers, cohesion of the inhabitants of municipalities, knowledge of social networks in the relations of the commercial sphere) in the individual or the collective dimension. The formation of methodologies that make it possible to conduct 
the measurement of social capital is in current scientific discourse unintegrated. With respect to the preparation of a suitable tool making the measurement of social capital possible, it is recommended to determine the utility value of social capital. The issue of a metric of social capital - qua non-commercially tradable capital - that examines its utility value in the localities/regions of the Czech Republic is so far not being dealt with. By investigating social capital it is for instance possible to assess more comprehensively the development of a locality/region (e.g. to identify in a timely manner the possibilities of investment distribution on the micro, mezzo, and macro level; or to specify the resources to be drawn from the EU structural funds by means of a systematic analysis of social networks, or to examine the erosion of trust towards investors.

The accumulatable ownership of social capital (private networks) represents individual advantage in connection with other kinds of capital (economic, cultural, symbolic). Thus generated individual advantage brings with it also negative manifestations of social capital, such as corruption, nepotism, patronage, protectionism, or mafia. Individual social capital thus can benefit the society's social capital, but likewise it can undermine the totality of this capital.

Empirical study of social capital was for the first time carried out by J. Coleman, on the micro and macro level. His work was carried on by R. Putnam, whose aim became the study of aggregate groups. Currently it is possible to note a boom in scientific research in this area, and most of all in the efforts at a revision of the comparative studies, particularly on the macro scale. Social capital has become the research subject of the social sciences and also of public discourse, chiefly in respect of its practical application (the study of criminality, neighbourhoods, corruption, public health, employment, the environment, etc). Social capital is a theme debated in particular within the conceptions of „society as a network", „the knowledge society“, or ,knowledge economics“.

\section{THE PRESENT CONCEPTS OF SOCIAL CAPITAL}

The sources or effects of social capital appear in the lexicon of everyday speech. Therefore, in the first phase of the subtask being dealt with, the attention of our investigation focuses on the delineation of social capital. For its ambiguity and vagueness, social capital is in some of the work of mainly foreign authors actually regarded as rather a metaphor than an analytical tool, and therefore its operationalization in social sciences is essentially dismissed; and consequently some theoreticians claim that it cannot be empirically studied (BARON, FIELD, SCHULLER; 2000; pp. 1-37). Proceeding from Putnam's concept of social capital we find that it is not possible to explain social capital unambiguously, since by its very nature it is multidimensional, or multi-indicator, as the author himself mentions. According to Putnam, the following is necessary - „Accepting that there is no single form of social capital, we need to think about its multiple dimensions." (PUTNAM; 2001; p. 45). ${ }^{1}$

We find it relevant to mention, as important sources of the concepts and theories of social capital and their representatives, the foundational sociological theories of the authors P. Bourdieu, J. Coleman and R. Putnam. Social capital is variously perceived in the context of each particular social science (LIN, 2002), and therefore the endeavour of empirical studies is to deal with the unintegrated definition of social capital - particularly through operationalization, which, however, reflects the subjective interpretation of the researcher. ${ }^{1}$

In order to capture the partial differences in each of the different concepts of the authors mentioned, and consequently for the sake of reflection on the possibilities of their practical applications within our research intention, I find it relevant to carry out a rough characterization of each of them.

\section{THE CONCEPT OF SOCIAL CAPITAL ACCORDING TO P. BOURDIEU}

P. Bourdieu conceives of social capital as "the aggregate of actual or potential resources that springs from the possession of a durable network of more or less institutionalised relationships and acquaintance in other words from membership in a group that provides each of its members with the collectively owned capital, that is, with various privileges."(BOURDIEU;

\footnotetext{
${ }^{1}$ On the basis of an extensive research analysis of literary sources we have discovered that the empirical studies carried out thus far are based on only a certain limited set of concepts of social capital, particularly then on the theory of R. Putnam. In this connection, it is possible to regard as representative projects (ISSP, CONSCISE 2002 Available at http://www. malcolmread.co.uk/conscise/supp3.htm) on the local, regional, national, and international level (OECD; the research tool SOCAT World Bank (2000) What is Social Capital? from www.worldbank.org/poverty; or UPHOFF 2000 ; EU-see e.g. PARISSAKI, M. - HUMPHREYS, E. 2005). Great attention is being paid to the measurement of social capital in Great Britain. An important initiative in this sense is the effort of the British Office for National Statistics (ONS), which seeks the standardization of social capital measurement - available at www.statistics.gov.uk/about ns/social_capital - in connection with environmental capital (noisiness, air pollution, garbage and their pick-up...);
} 
1986; p. 249) (BOURDIEU - WACQUAANT; 1992; p. 119)

In connection with P. Bourdieu's theory of the structure of society and his definition of cultural and symbolic capital it is possible to infer that the sources of social capital can be employed to overcome inequalities arising from the social structure. The individual, who is part of the social group, disposes of his/her social capital as property that can be gained by means of objective social flows (social relations) in classes/groups. "I contrast reduction to a conscious calculation with the relationship of ontological harmony between habitus and field". (BOURDIEU; 1998; p.109). The individual's advantage is realized by a social pattern of habitus perception, supported by the structure. The advantage is made possible by a structural solidarity of functional social relationships.

\section{THE CONCEPT OF SOCIAL CAPITAL ACCORDING TO J.COLEMAN}

J. Coleman delineates social capital in connection with human and physical capital and with the study of the reproduction of social inequality. Social capital in his theory is instrumental to the attainment of both individual and collective goals that can be fulfilled through functional relationships, or as it were through purpose-driven conduct of agents aiming at advantage. This means that social structure influences the formation of relationships and the form of social networks. Coleman defines social capital as a function of an advantage-producing social structure (COLEMAN; 1988; pp. 98-105), which means that even with this concept it is possible to perceive that by means of social capital the individual manages to overcome a handicap arising for instance from economic barriers, something he agrees with Bourdieu on. He further defines social capital in this way: "Social capital is defined by its function. It is not a single entity but a variety of different entities having two characteristics in common: they all consist of some aspect of social structure, and they facilitate certain action of individuals who are within the structure. Like other forms of capital, social capital is productive, making possible the achievement of certain ends? that would not be attainable in its absence." (Ibid. p. 98.)

Social capital as the equipment of the agent/agents facilitates action and the possibility of receiving information within the social structure. In his view social capital does not represent the agent's private property. Coleman, unlike Bourdieu, delineates social capital into the following forms:

- obligations, expectations, and trustworthiness of structures - the elements are trustworthiness of the social environment (trustworthiness of insti- tutions) and the current extent of the agents' commitments. "This form of social capital depends on two elements: trustworthiness of the social environment, which means that obligations will be repaid and the textual extent of obligations upheld. Social structures differ in both these dimensions, and actors within the same structure trigger the second." (Ibid. p. 102)

- information channels - social capital means the opportunity to receive information that is contained in social relationships and safeguards action. "An important form of social capital is the potential for information that inheres in social relations. ...a person who is not greatly interested in current events but who is interested in being informed about important developments can save the time of reading a newspaper by depending on spouse or friends who pay attention to such matters." (Ibid. p. 104)

- norms and effective sanctions - the effective establishment of norms and sanctions promotes collectivity and general welfare (through the agent's surrendering his/her own personal interests) by means of closed social networks (and the density of the networks). "When a norm exists and is effective, it constitutes a powerful, though sometimes fragile, form of social capital.... A norm in a community that supports and provides effective rewards for high achievement in school greatly facilitates the school's task." (Ibid. p. 104).

Coleman's conception combines individual social capital with the community's capital, individual capital determining (through cooperation, reciprocity, etc...) the capital of the community that is composed of these individuals - and therefore the aforementioned sorts of capital are not in conflict with each other.

\section{THE CONCEPT OF SOCIAL CAPITAL ACCORDING TO R. PUTNAM}

The theoretical point of departure of R. Putnam's concept is social capital going beyond community boundaries and contributing to the social cohesion of society in its entirety. He bases his definition of social capital on communitarism and the paradigm of consensus. He views social capital as a composite, multifaceted dimension of formal and informal forms (membership in an organization, a picnic, a queue of shoppers). In his definition he states that "social capital refers to the attributes of social organization, such as trust, norms and networks that facilitate coordinated action and thus contribute to the efficiency of society." (PUTNAM; 1993; p. 167) "The central idea of social capital, in my view, is that networks and the associated norms of reciprocity have value. 
They have value for the people who are in them, and they have, at lest in some instances, demonstrable externalities, so that there are both public and private faces of social capital."

In connection with his concept of social capital we encounter his view of social trust. Trust contributes to cooperation and collective action. His perception of trust is as follows: „... social trust is not part of the definitions of social capital but it is certainly a close consequence, and therefore could be easily thought of as a proxy.“"(PUTNAM; 2001; pp. 45-51)

An ingredient of Putnam's concept of social capital is also typologization, arising from the function of social capital in a group/community/society. He considers the individual types of social capital to be the following:

- Bridging, inclusive social capital, which manifests itself externally, i.e. for instance among groups, as a movement across society, in the cohesion of society as a whole, in its knowledgeability.

- Bonding, exclusive social capital, acts within groups, in the cohesion of groups, in solidarity, reciprocity - for instance within the framework of an ethnicity, a class...

Putnam's concept has encountered criticism directed at a whole range of aspects. Among other things, he is being faulted for his technique of data aggregation and for the limitation of applications to settings with attributes typical of the USA. The originality of this concept lies in the fact that more than the preceding concepts it sees the effects of social capital precisely in the existence of social networks, rather than in the individual's social capital.

\section{DEFINITIONS OF SOCIAL CAPITAL ELABORATED FROM SOURCE CONCEPTS}

Besides the clearly delineated theoretical concepts of social capital held by Putnam, Bourdieu, and Coleman, there exist in professional literature various other interpretations of this sociological category. We mention only those that we consider representative, by way of illustration.

The connections among the individual concepts are reflected in the dimensions of the sources of capital, in individualism or collectivism, in social structure, and in the transfer to the area of the culture/knowledge of the individual and society (via various communication media - influence, economic means, information, knowledge etc, on the formal and informal level). The definition of social capital is reflected in the context of the social sciences. ${ }^{2}$ Social capital strengthens organized cooperation among citizens, by which it contributes to the efficacy of social institutions. In this way it would be possible to interpret the view of social capital in German sociology. "Social capital describes - to phrase it generally - the society's ability to generate social solidarity of citizens and institutions." (BAYER; 2004; p. 37) It is possible to identify a certain overlap of social capital in cognitive practice, for instance the formation of citizens' attitudes, even in Offe's definition: " Social capital is a socially moral resource, deriving from cultural tradition, everyday routines and conventions, and available just as much to local communities as to entire societies." (BAYER; 2004; p. 37)

A point of departure particularly for Putnam's conception of social capital is apparent in the definition of Bayer, who dwells on the agents' interpersonal skills that manifest themselves in solidarity, cohesion, and trust. "Social capital is understood to be the basis of social cohesion: it stabilizes general trust, engenders in citizens a sense for the issues of civil society and fosters the ability of integration." (BAYER; 2004; p. 37-38)

Social capital in the work of the above-mentioned authors thus differs not just conceptually, but also in the methodology used - an example is the analysis of so-called soft and hard data.

\section{A PARTIAL CONCLUSION}

Comparison of the concepts of social capital held by Bourdieu, Coleman and Putnam shows certain differences according to whether the source of social capital is in individualism or collectivism, and similarities in the manifestation of social capital in the social structure and in the transfer of social capital to culture/knowledge. Thus for the sake of quick orientation We have compiled a survey chart (see Chart 1). As criteria on the basis of which to differentiate the concepts described we have chosen what in my judgement are typical, shared, and yet by each individual author differently perceived, features.

\footnotetext{
${ }^{2}$ See e.g. in the economic sphere WOOLCOCK, 1998; WOOLCOCK, 2000; WOOLCOCK, 2001
} 
I: Comparison of the concepts of social capital

\begin{tabular}{|l|l|l|l|}
\hline Author & $\begin{array}{l}\text { Source in individualism/ } \\
\text { collectivism }\end{array}$ & $\begin{array}{l}\text { Manifestation } \\
\text { in the structure of society }\end{array}$ & $\begin{array}{l}\text { Transfer to culture/ } \\
\text { knowledge }\end{array}$ \\
\hline Bourdieu & $\begin{array}{l}\text { acquisition of advantages } \\
\text { for the ego (private social } \\
\text { property) in connection } \\
\text { with habitus } \\
\text { individual advantages produce } \\
\text { 'public' side benefits. }\end{array}$ & $\begin{array}{l}\text { position, statuses, classes, } \\
\text { intergenerational mobility, } \\
\text { networks, relationships, } \\
\text { inequalities }\end{array}$ & $\begin{array}{l}\text { culture, education, attitudes, } \\
\text { trust } \\
\text { networks }\end{array}$ \\
\hline Putnam & $\begin{array}{l}\text { 'public' advantages of } \\
\text { engagement in shared } \\
\text { activities stabilize society }\end{array}$ & $\begin{array}{l}\text { communities, regions, nation, } \\
\text { networks, bonds, cohesion }\end{array}$ & $\begin{array}{l}\text { solidary organizedness, } \\
\text { community participation, } \\
\text { reciprocity, values, attitudes, } \\
\text { trust }\end{array}$ \\
\hline
\end{tabular}

Source: author

The above-mentioned basic characteristic features apart, the individual authors also differ in how they perceive the issue of whom social capital brings benefit to; however, they agree that among the participants its effect is one of mutual support, arising from a consciousness of a subjective and even objective contribution to the individual/group, of group affili- ation/of close connection with the individual. Who markedly differs from Bourdieu and Coleman is precisely Putnam. We have elaborated the differences of this sort in Chart 2, whose basic features were presented at a seminar held by the Institute of Sociology of the Academy of Sciences of the Czech Republic on October $20^{\text {th }}, 2005$.

II: Differences of social capital

\begin{tabular}{|c|c|c|c|}
\hline Author & Forms & Types & Application \\
\hline \multirow[t]{2}{*}{ Bourdieu } & \multirow[t]{2}{*}{ Individual } & Mobilizational & $\begin{array}{l}\text { - access to education } \\
\text { - job search } \\
\text { - a means (instrument) of success } \\
\text { - tapping into local acquaintance (entrepreneurs, } \\
\text { politicians, physicians, lawyers, teachers ...) }\end{array}$ \\
\hline & & Interactive & $\begin{array}{l}\text { - numerousness of visits to social functions } \\
\text { (clubs, restaurants, neighbours, relatives, } \\
\text { church services ...), } \\
\text { - phoning by time unit }\end{array}$ \\
\hline \multirow{2}{*}{ Putnam } & \multirow{2}{*}{ Collective } & Aggregate statistical data & $\begin{array}{l}\text { - numbers of local associations organizations } \\
\text { - membership lists } \\
\text { - sponsor lists }\end{array}$ \\
\hline & & Individual affirmations & $\begin{array}{l}\text { - inquiry about membership in local associations } \\
\text { - voluntary social activity } \\
\text { - reasons for sponsorship }\end{array}$ \\
\hline
\end{tabular}

Source: Elaborated on the basis of Šafr-Sedláčková, 2005

PROPOSAL OF AN APPROACH

TO THE IDENTIFICATION OF SOCIAL CAPITAL IN LOCALITY/REGION FOR THE SOLUTION OF THE SUBTASK WITHIN THE FRAMEWORK OF THE RESEARCH INTENTION

Empirical sociological research, particularly its informative value, is directly dependant on the met- ric employed. The practice of sociological fieldwork utilizes in this respect various identifiers. In the interpretation of these quantities is then reflected the particular experience of the person conducting the study and at the same time the specificities of the region in which the study of social capital is being carried out. 
On this count we consider especially significant the experience of the British Office for National Statistics, from which derives the fundamental conclusion of a certain universality of interpretation of social capital and at the same of the uniqueness of the identifiers used in its quantification. A decisive role in the selection of a particular set of identifiers for a study with a particular aim will thus be played by the specificities of the region in which the analysis of social capital will be carried out. A preparatory phase of a study focused precisely on these problems will then significantly reduce the risk of the occurrence of those errors in which the effects of social capital (PORTES, 1998) are confused with its causes. This problem is relatively often mentioned in the information put out both by SOCAT and by the British Office for National Statistics.

The relevance of the study of local/regional capital, in particular of social capital, represents in our circumstances a necessary condition for the analysis of social networks. Communication and cooperation shows certain specificities in rural areas and in conurbations. (social capital breaking up on the mezzo level). These specificities are different compared with similar studies conducted in other European regions. ${ }^{3}$ A significant feature of our milieu is the stereotypical overestimation particularly of the influence of social capital on the development of a locality/ region. The current connection to financial capital will in the future cease to carry weight. The overestimation of the role of this sort of capital proves that the society operates with marked post-totalitarian symptoms, which manifest themselves in the public sphere, state administration, and education, on all levels. This, quite naturally, has logical implications also with the functioning of the entrepreneurial sphere and with the economy as a whole. It is therefore necessary to conduct an in-depth analysis of these specificities before the traditional methods of sociological research are applied.

What becomes a competitive advantage on the level of locality/region is thus untradable social capital, which together with other kinds of capital of non-financial character is an element of the theory of "the knowledge society" (VESELÝ, 2004), or "the network society." These concepts represent a way-out from the situation where financial capital can no longer be sufficient for the development of the locality/region, and where it is desirable for there to occur advancement of interests "from below" and synergic effects. What serves to identify these tendencies is the conducting of an analysis of social capital formation in a particular place. The elaboration of the conceptual apparatus and research methodology is thus a point of departure for empirical research that will focus on other social capital connections, for instance with the socioprofesional structure of a region, all within the framework of the research intention subtask.

A point of departure for research and for the formation of one's own research tool is in our view $P$. Bourdieu's concept, due to the specificities of our conditions - mobilizational individual capital and its manifestations in identification with the environment. Social capital is becoming part of the social experience of individuals, communities, members of social groups, by whom it is being interpreted and transformed into action, and therefore it is also a factor that can curb negative globalizing tendencies.

For the purposes of the research intention, it is necessary to determine the typology of regional and network structures via approaches to the metric of social capital. On the basis of the study of social capital concepts and with respect to the sustainable development of multifunctional agriculture, the research topics that are becoming fundamental are the individual's activity and his/her social interactions institutionalised in social networks, furthermore conflicts and related manifestations of solidarity that affect cohesion and manifestations of trust towards institutions. Likewise not to be omitted are narrativized constructions (HUBÍK, 2004) of a sensation of local identity. In order to capture the individual dimensions of the approaches mentioned we have compiled Chart 3.

\section{CONCLUSION}

Definintions of social capital is itself problematic. There are many conditions to be fulfilled in identification of social capital in multifunctional agriculture. The aim of the research intention of the thematic aim is the conducting of an analysis of social capital formation in a particular place (locality/region). For the purposes of the research intention, it is necessary to determine the typology of regional and network structures via approaches to the metric of social capital.

\footnotetext{
3 See e.g. MATĚJŮ, 2002.
} 
III: Individual dimensions of the approaches of social capital

\begin{tabular}{|l|l|}
\hline Approaches & Dimensions \\
\hline $\begin{array}{l}\text { Actual and possible kinds of partici- } \\
\text { pation in local groups' activities }\end{array}$ & $\begin{array}{l}\text { - cooperation within the framework of local relations } \\
\text { - perceived barriers to membership in local groups } \\
\text { - extent of involvement in local groups } \\
\text { - preference of local social formations }\end{array}$ \\
\hline $\begin{array}{l}\text { Current and potential mobilization } \\
\text { of social networks }\end{array}$ & $\begin{array}{l}\text { - sensation of the extent of influencing local changes } \\
\text { - effort exerted in mobilizing the network } \\
\text { - participation in the solution of local problems } \\
\text { - offering or receiving help, support } \\
\text { - entrances into acquaintance networks } \\
\text { - use of formal and informal networks } \\
\text { - density of social networks } \\
\text { - the durability of a private social network } \\
\text { - loss of social networks (loss of the meaning of a relation) }\end{array}$ \\
\hline wards institutions & - the relating of conflict \\
& - length of residence in a locality \\
\hline
\end{tabular}

Source: author

\section{SOUHRN}

Východiska redefinování sociálního kapitálu v podmínkách agrárního sektoru v České republice

Cílem článku je podat přehled o přístupech ke zkoumání sociálního kapitálu a předložit návrh konceptu sociálního kapitálu, kterým by byla umožněna kvantifikace tržně nerealizovatelného kapitálového potenciálu z hlediska udržitelného rozvoje multifunkčního zemědělství. Identifikace sociálního kapitálu zohledňuje specifika našeho prostředí - mobilizační individuální kapitál a jeho projev v identifikaci s prostředím pro postižení jednotlivých dimenzí v uvedeném př́ístupu.

koncepty sociálního kapitálu, formy sociálního kapitálu, lokalita/region, udržitelný rozvoj, multifunkční zemědělství

Tento příspěvek vznikl v rámci řešení výzkumného záměru PEF MZLU v Brně, MSM 6215648904 „Česká ekonomika v procesech integrace a globalizace a vývoj agrárního sektoru a sektoru služeb v nových podmínkách evropského integrovaného trhu“.

The paper has arisen within the research project of FBE MUAF Brno, MSM 6215648904 „Czech economy in the process of integration and globalization and the development of agrarian sector and sector of services in new conditions of European integrated market“".

\section{REFERENCES}

BARON, S., FIELD, J., SCHULlER, T.: Social capital: A review and Critique. Social capital: critical perspectives. Oxford University Press, 2000, p. 307.

BAYER, I.: Sociální soudržnost z pohledu německé sociologie. In: MUSIL, J. Studie CESES - Pojetí sociální soudržnosti v soudobé sociologii a politologii. Praha: FSV UK CESES, 2004, No. 9., pp. 36-49.
BOURDIEU, P.: The forms of Capital. In: Richardson, J. G.: Handbook of Theory and Research for the Sociology of Education. New York: Greenwood Press, 1983, pp. 241-258.

BOURDIEU, P.: Teorie jednání. Praha: Karolinum 1998.

BOURDIEU, P., WACQUANT, J. D.: An Invitation to Reflexive Sociology. Chicago, IL: University of Chicago Press, 1992, p. 119.

COLEMAN, J. S.: Social Capital in the Creation 
of Human Capital. American Journal of Sociology, 1988, Vol. 94, pp. 95-120.

HUBÍK, S.: Sociální konstrukce místního/regionálního kapitálu (metoda). Sborník prací z mezinárodní vědecké konference Agrární perspektivy XIII. Praha: PEF ČZU, 2004, s. 404-409.

Knowledge Management in the Learning Society. Education and Skills. 2000. Paris: Centre for Educational Research and Innovation OECD. pp. 11-35.

LIN, N.: Social capital: A theory of social structure and action. Cambridge: Cambridge University Press, 2002, 278 p.

MATĚJŮ, P.: Social capital. Problems of its conceptualization and measurement in transforming societies. Social capital: The challenge of international measurement. London: OECD - ONS, 2002.

PARISSAKI, M., HUMPHREYS, E.: Regional social capital in Europe. Dublin: European foundation for the Improvement of Living and Working Conditions, 2005, pp. 1-112.

PORTES, A.: Social capital: Its origins and applications in modern sociology. Annual Review of Sociology. Palo Alto: 1998, Vol. 24, pp. 1-12.

PUTNAM, R.: Making Democracy Work: Civic Tradition in Modern Italy. Princeton, NJ: Princeton University Press, 1993, pp. 167.

PUTNAM, R. D.: Social Capital Measurement and Consequences. ISUMA - Canadian Journal of Policy Research, 2001, Vol. 2, No. 1, pp. 45-51.
ŠAFR, J., SEDLÁČKOVÁ, M.: Koncepty a indikátory sociální koheze - východiska empirických výzkumů. In: MUSIL, J. Studie CESES - Pojetí sociální soudržnosti v soudobé sociologii a politologii. Praha: FSV UK CESES. No. 9., pp. 17-35.

ŠAFR, J., SEDLÁČKOVÁ, M.: The seminar "Concepts of social capital". IS AS of the CR, 2005, Praha 20. 10. 2005

UPHOFF, N.: Understanding Social Capital: Learning from the Analysis and Experience of Participation. s. 215-249. In DASGUPTA, P. - SERAGELDIN: Social Capital: A multiperspective approach. Washington D.C.: The World Bank, 2000.

VESELÝ, A.: Budování společnosti a ekonomiky tažené věděním. Strategické tahy pro Českou republiku. Praha: CESES UK, 2004, pp. 24-57.

WOOLCOCK, M.: Social Capital and Economic Development: toward theoretical synthesis and policy framework. In: Theory and Society, 1998, Vol. 27, pp. 151-208.

WOOLCOCK, M., NARAYAN, D.: Social capital: Implications for Development Theory, Research, and Policy. In The World Bank Research Observer, 2000, Vol. 15, No. 2 August 2000, pp. 225-249.

WOOLCOCK, M.: The Place of Social Capital in Understanding Social and Economic Outcomes. ISUMA - Canadian Journal of Policy Research, 2001, Vol. 2, No. 1, spring 2001.

Mgr. Nataša Pomazalová, Ústav humanitních věd, Mendelova zemědělská a lesnická univerzita v Brně, Zemědělská 1, 61300 Brno, Česká republika, e-mail: pomazalo@mendelu.cz 